\title{
Protection of Intellectual Property Rights in Russia: Novels Civil - Legal Regulation
}

\section{Anna Petrovna Rabets}

Far Eastern Federal University
Email: anita_trof@mail.ru

Doi:10.5901/mjss.2015.v6n3s6p257

\section{Abstract}

The article is devoted to new provisions of the Russian civil legislation in the intellectual rights protection sphere. The legal analysis of the specified short stories gains relevance and the importance in connection with entering of essential changes into the fourth part of the civil code of the Russian Federation regulating the legal protection of intellectual property. The research objective was definition effective civil - legal rights mechanism protection for objects of the intellectual property taking into account changes in the legislation. The specified purpose defined need of the solution of the following tasks: to investigate relation, and also protection and responsibility measures specifics in the considered sphere; to reveal features of application of new legislative designs in the field of protection of the intellectual rights; to consider features of collecting monetary compensation for violation of an exclusive right. The specified tasks were solved with the use of general scientific and private scientific methods. In the research are formulated the offers and recommendations promoting uniform application of norms of civil law in the case of violation of the intellectual rights. In particular, the conclusions of the distribution of the provisions of the civil legislation of the Russian Federation about the increased responsibility of entrepreneurs in the field of non-contractual breach of intellectual property rights. In general is supported the aspiration of the Russian legislator to the improvement of legal categories in the intellectual rights protection field.

Keywords: intellectual rights; protection; responsibility measures; legislation; compensation.

\section{Introduction}

The problem of the fight against violations of the rights on objects of intellectual property by means of measures civil legal character is rather actual for Russia. Preservation and accumulation of creative potential, development of economy, an increase of the international authority of the country in many respects depends on its decision.

Civil - legal regulation of the intellectual rights protection is carried out by the fourth part of the Civil Code of the Russian Federation (the section VII "The rights for results of intellectual activity and means of an individualization") which came into force on January 1, 2008. At the same time, practically from the moment of the specified document adoption its structural and substantial defects came to light, on what was looked for the attention in legal literature (Eremenko, 2007, p.43) and in the Concept of development of the civil legislation of the Russian Federation (Note 1).

It is possible to allocate some reasons which induced the legislator to make essential changes to the fourth part of the Civil Code of the Russian Federation (further - the Civil Code of the Russian Federation) in six years after its introduction in action.

First, modern conditions of economic development of the country, including technical modernization, demanded further improvement of the legal regulation of the relations in the field of objects of intellectual property.

In - the second, many unresolved questions became known during use of the fourth part of the Civil Code of the Russian Federation: ratio of the real and intellectual rights; application of pledge of an exclusive right and others. As a rule, the specified problems were connected with insufficient legal definiteness of separate provisions of the Section VII of the Civil Code of the Russian Federation.

In - the third, at acceptance mentioned standardly - the legal act the questions caused scientifically - technical progress, development of the Internet and other information telecommunication networks did not receive the adequate decision. These defects and further commercialization of intellectual property entailed mass violations of the intellectual rights in the field.

"Doted" changes of the civil legislation were directed to the solution of the above problems. Therefore, article 1253.1 of the Civil Code of the Russian Federation of "Feature of responsibility of the information intermediary" was entered by the Federal law of July 2, 2013 No. 187 - Federal Law. However improvement of legal regulation of intellectual property protection required the complex changes made to the fourth part of the Civil Code of the Russian 
Federation by the Federal law of March 12, 2014 No. 35-Federal Law "About modification of parts the first, second and fourth the Civil Code of the Russian Federation and separate acts of the Russian Federation".

The general analysis of the contents of the Federal law, which came into force on March 12, 2014. "About modification of parts the first, second and fourth the Civil Code of the Russian Federation and separate acts of the Russian Federation" allows to draw a conclusion on emergence in the Civil Code of the Russian Federation of important short stories in the field of protection of the intellectual rights bringing the domestic legislation in the sphere of intellectual property to qualitatively new level. Therefore, in chapter 69 of the Civil Code of the Russian Federation practically all general provisions devoted to protection of the specified rights underwent editing (article 1248, 1250, 1251, 1252, 1253, and 1254 of the Civil Code of the Russian Federation). Besides, changes affected also rules about protection of the intellectual rights objects of intellectual property: objects of copyright and allied rights; objects of patent law; trade names, names of places of goods origin (Note 2).

Thus, change of the provisions of the civil legislation concerning an order and ways of protection of the intellectual rights demands scientific research of new rules and detection of features of their application. In this regard, the legal analysis of the specified short stories gains relevance and the importance.

\section{The Literature Review}

The studying questions connected with research of a broad range of the problems, which are available in the sphere of protection of the intellectual rights, scientific works of such authors as I.A. Bliznets, E.P. Gavrilov, O.A. Gorodov, A.P. Sergeev, V.A. Dozortsev and V.I. Eremenko are devoted. The considered problems partially were analyzed in theses on competition of an academic degree of the candidate of jurisprudence: O.V. Makarova, E.V. Zykova, I.V. Tsvetkova and some other authors.

At the same time, the overwhelming number of scientific publications was published before introduction in 2014 of essential changes part the fourth the Civil Code of the Russian Federation. The analysis of new provisions of the civil legislation in the sphere of intellectual rights protection is carried out, in particular in scientific works of L.A. Novoselova, E.P. Gavrilova. However, in general, the specified questions in the Russian jurisprudence are investigated obviously insufficiently.

\section{Methods and Materials}

The subject of this research is the norms of Russian civil law governing the protection of intellectual property rights discussed in the theoretical and practical aspects.

The methodological basis of the study served as scientific methods of knowledge (analysis, synthesis, generalization, induction, deduction), as well as private - scientific methods of learning: formal - legal and comparative legal. Application of these methods allowed exploring new rules in the field of protection of intellectual property rights holistically and comprehensively.

\section{Results and Discussion}

The order the intellectual rights protection did not undergo essential adjustments. On former, the primary order of the rights protection for intellectual property objects is a legal process, special - administrative. However the instruction on possibility of consideration and permission administratively of the disputes connected with protection of the intellectual rights in Chamber on patent disputes is excluded (item 3 of article 1248, article 1398, item 1 of article 1513 of the Civil Code of the Russian Federation in edition of the Federal Law of 12.03.2014 No. 35-Federal Law).

According to the point of view, widespread in the legal literature, ways of protection of the civil rights can be subdivided into measures of protection and responsibility (Krasavchikov, 1973, pages 9-12). Responsibility measures are applied to the person whom the guilty and illegal actions violated the rights protected by the law and interests of the owner and expressed in additional encumbrances in the form of deprivation of the violator of certain rights or assignment of it additional duties. In turn, for the application of measures of protection it is not required the existence of fault and illegality in actions of the obliged subject.

Let's notice that the specified classification of ways of protection of the civil rights initially found the reflection in Art. 1250 of the Civil Code of the Russian Federation in relation to ways of protection of the rights for objects of intellectual property, and then was concretized by the Federal law of March 12, 2014. "About modification of parts the first, second and fourth the Civil Code of the Russian Federation and separate acts of the Russian Federation." So, in item 5 of article 
1250 of the Civil Code of the Russian Federation (in edition of the Federal Law of 12.03.2014 No. 35-Federal Law) provides the list of measures civil - legal protection of the intellectual rights which are applied and in the absence of fault of the violator. The legislator carries the publication of a judgment about the allowed violation to the specified measures, suppression of the actions violating an exclusive right or creating a threat of such violation, withdrawal and destruction of counterfeit material carriers. We believe that former edition of the considered norm was correct because did not affirm a measure of protection the intellectual rights in the form of the closed list. For example, such way of protection of the intellectual rights as recognition of the right, item 5 of article 1250 of the Civil Code of the Russian Federation which is not specified in the new edition, pursues first of all the right recovery aims directed on protection of the rights of authors, other owners and also possesses other signs, characteristic for measures civil - legal protection.

Responsibility measures for violation of the intellectual rights are established in item 3 of article 1250 of the Civil Code of the Russian Federation (in edition of the Federal Law of 12.03.2014 No. 35-Federal Law) according to which "the responsibility measures for the intellectual rights violation provided by the present Code are subject to application in the presence of fault of the violator if other is not established by the present Code". Let's notice that article 1250 of the Civil Code of the Russian Federation does not provide the exhaustive list of measures of responsibility in the considered sphere that is quite justified. In paragraph, 3 of item 3 of article 1250 of the Civil Code of the Russian Federation in the new edition indemnification and payment of compensation for violation of an exclusive right are carried to measures of responsibility for violation of the intellectual rights.

It should be noted that in the above fragment of article 1250 of the Civil Code of the Russian Federation there was an interesting short story according to which if other is not established by the Code, indemnification and payment of compensation for violation of the intellectual rights are subject to application irrespective of fault of the violator if such person does not prove that violation of the intellectual rights happened owing to force majeure. Thus, violation of the specified rights has to be allowed for implementation of the business activity. The analysis of paragraph 3 of item 3 of article 1250 of the Civil Code of the Russian Federation (in an edition of the Federal Law of 12.03.2014 No. 35-Federal Law) allows drawing the following conclusions.

In - the first, at the implementation of business activity the person bears property responsibility for violation of the intellectual rights not only in the presence of a fault, but also for casual violation. Thus the person to whom in the absence of his fault measures civil - the legal responsibility having the right to impose regressing requirement about compensation of the suffered losses including the sums paid to the third parties (item 4 of article 1250 of the Civil Code of the Russian Federation) are applied. Presentation of the specified requirement is possible in case of payment by the innocent person of losses or compensation, and in the event of withdrawal from it the material carrier in which the object of intellectual property is expressed. Thus, if the violator is responsible for the fault, he is deprived opportunity to impose the regressing requirement.

In - the second, the violator of the intellectual rights at implementation of business activity is subject to release from civil - legal responsibility only at commission of violation owing to force majeure, which is circumstances extraordinary and irresistible under existing conditions.

In - the third, provisions of the legislation on the increased responsibility of businesspersons (item 3 of article 401 of the Civil Code of the Russian Federation) are distributed now and to the non-contractual sphere.

In the legal literature, various theories explaining the application of measures civil - legal responsibility irrespective of fault and even are stated at its absence (A.S. Shevchenko and G.N. Shevchenko, 2013, pages 60-61). We believe that it is possible to agree with the arguments stated on the matter by lawyers - supporters of the concept of "fault with an exception", acknowledging the possibility of an exception to the principle of guilty responsibility (Sukhanov, 2010). Thus, considering, that the law directly calls the considered case responsibility (paragraph 3 of item 3 of Art. 1250 of the Civil Code of the Russian Federation in Federal Law edition of 12.03.2014 No. 35-Federal Law), in the civil legislation it is possible to conclude that there was one more case of without fault responsibility, which is directly established by the law.

Finishing the characteristic of the division of ways of the intellectual rights protection for measures of protection and measures of responsibility it should be noted some inconsistency of the legislator when using the mentioned categories. So, measures of protection of the intellectual rights though the speech goes about measures of civil responsibility are referred to in item 4 of article 1250 of the Civil Code of the Russian Federation.

The legislation contains the classification of ways of protection of the intellectual rights and by another criterion in the sphere of intellectual property, namely - by the legal nature of the violated rights. According to article 1226 of the Civil Code of the Russian Federation on results of intellectual activity and means of an individualization equated to them the intellectual rights, which include admit: a) the exclusive right which is a property right; b) the personal non-property rights in the cases provided by the Civil Code of the Russian Federation; c) other rights (right of following, right of access, etc.) in the cases offered by the Civil Code of the Russian Federation. According to the specified approach in the Civil Code of 
the Russian Federation ways of protection of the personal non-property rights (article 1251 of the Civil Code of the Russian Federation in edition of the Federal Law of 12.03.2014 No. 35-Federal Law), in particular, recognition of the right are allocated; recovery of the provision existing before violation of the right; suppression of the actions violating the right or creating threat of its violation; compensation of moral harm; the publication of a judgment about the allowed violation. In turn, in the new edition the legislator fixes ways of protection of an exclusive right in article 1252 of the Civil Code of the Russian Federation (recognition of the right; suppression of the actions violating the right or creating threat of its violation; indemnification; withdrawal of the counterfeit material carrier in which the result of intellectual activity or means of an individualization is expressed; the publication of a judgment about the allowed violation; compensation for breaches of exclusive rights and others).

The federal law of March 12, 2014. "About modification of parts the first, second and fourth the Civil Code of the Russian Federation and separate acts of the Russian Federation" made some changes to the above provisions of the Civil Code of the Russian Federation. Thus, article 1252 of the Civil Code of the Russian Federation underwent an essential adjustment. For example, in the considered article the new basis of the application of a joint liability received fixing. According to item 6.1 of article 1252 of the Civil Code of the Russian Federation in edition of the Federal Law of 12.03.2014 No. 35-Federal Law in case one violation of an exclusive right to result in intellectual activity or means of an individualization is made by actions of several persons in common, such persons answer to the owner solidary. Apparently, the specified situation corresponds to the rule established in Article 1080 of the Civil Code of the Russian Federation "Responsibility for in commonly done harm".

Further, in the new edition article 1252 of the Civil Code of the Russian Federation possible collisions of exclusive rights not only to various means of an individualization, but also on the means of an individualization and industrial samples belonging to different owners are considered. "If means of an individualization and an industrial sample are identical or similar to extent of mixture and as a result of such identity or similarity consumers and (or) contractors can be misled, means of an individualization or an industrial sample the exclusive right concerning which arose earlier, or in cases of establishment of conventional, exhibition or other priority means of an individualization or an industrial sample concerning which earlier priority is established has advantage" (paragraph 2 of item 6 of article 1252 of the Civil Code of the Russian Federation in edition of the Federal Law of 12.03.2014 No. 35-Federal Law).

In item 2 of article 1252 of the Civil Code of the Russian Federation, interim measures of claims for affairs in the sphere of violation of exclusive rights are corrected. So, it is in addition specified that such measures have to be proportional to the volume and character of an offense. Besides arrest on material carriers, the equipment, and materials, also the ban on implementation of the corresponding actions in information and telecommunication networks is imposed.

At last, very significant changes also concerned such widespread way of protection of an exclusive right to payment of compensation for the violation of this right. Research of the regulations on compensation for violation of an exclusive right containing in item 3 of article 1252 of the Civil Code of the Russian Federation in edition of the Federal Law of 12.03.2014 No. 35-Federal Law, and also rules of the Civil Code of the Russian Federation about application of the considered way of protection to separate objects of intellectual property allows to note the following.

In - the first, the Federal law of March 12, 2014. "About modification of parts the first, second and fourth the Civil Code of the Russian Federation and separate acts of the Russian Federation" article 1406.1 of the Civil Code of the Russian Federation according to which in case of violation of an exclusive right to the invention, useful model or an industrial sample the owner along with use of other applicable ways of protection and measures of responsibility has the right to demand at the choice from the violator instead of compensation payment indemnification is entered.

At the same time, despite a similar positive innovation, payment of compensation for violation of an exclusive right on former is not a universal way of protection of the intellectual rights because it is not applied to violation of an exclusive right to selection achievement, know-how, a trade name, commercial designation, topology of an integrated chip. In view of the importance of the mentioned results of creative activity and means of an individualization, and considering practical difficulties with calculation of the claimed damages in appropriate cases, establishment of application of payment of compensation at violation of exclusive rights to all objects of intellectual property is advisable. Similar opinions were expressed and in the legal literature (Batakhov, 2013, pages 52-56).

In - the second, the Federal law of March 12, 2014. "About modification of parts the first, second and fourth the Civil Code of the Russian Federation and separate acts of the Russian Federation" concretized compensation calculation options. At the statement of requirements for compensation of compensation the owner of an exclusive right can choose one of two or three options for determination of the amount of compensation specified in paragraphs the second, third, fourth article 1301, paragraphs the second, third, fourth article 1311, paragraphs the second, third article 1406.1, subparagraphs 1 i 2 of point 4 of article 1515, subparagraphs 1 and 2 of point 2 of article 1537 of the Civil Code of the Russian Federation (in edition of the Federal Law of 12.03. 2014 No. 35-Federal Law). Let's note that the legislator 
specified compensation calculation option fixed in paragraph 4 of article 1301, paragraph 4 of article 1311, paragraph 3 of Article 1406.1 of the Civil Code of the Russian Federation. So, if the owner declared the requirement about payment of compensation in a double size of cost of the right of use of work, object of allied rights, the invention, the useful model, an industrial sample or the trademark defined proceeding from the price which under comparable circumstances is usually raised for their lawful use that method of application which was utilized by the violator has to be considered. We believe that the similar specification should be brought and in subparagraph 2 of point 4 of article 1515 of the Civil Code of the Russian Federation "Responsibility for illegal use of the trademark".

Thirdly, according to paragraph 3 of item 3 of article 1252 of the Civil Code of the Russian Federation (in edition of the Federal Law of 12.03. 2014 No. 35-Federal Law) if are violated by one action the rights for some results of intellectual activity or means of an individualization, the amount of compensation is defined by court for each illegally used result of intellectual activity or means of an individualization. The specified situation is subject to application in cases when one action violated an exclusive right on slightly results of intellectual activity or means of an individualization belonging to one subject, connected among themselves: verbal trademark and same commercial designation; trademark and industrial sample; some trademarks owned by the owner; work and the trademark using security and capable part of this work, etc.

As it was noted, in the above situations the amount of compensation is defined by the court for each illegally used object of intellectual property. Thus in case the rights for the corresponding results of intellectual activity or means of an individualization belong to one owner, the general amount of compensation for violation of the rights of them taking into account character and consequences of violation can be reduced by court below the limits set by the present Code, but cannot make less than fifty percent of the sum of the minimum amount of all compensations for the allowed violations (paragraph 3 of item 3 of article 1252 of the Civil Code of the Russian Federation in edition of the Federal Law of 12.03. 2014 No. 35-Federal Law).

Let's notice that according to the former edition of paragraph 3 of item 3 of Art. 1252 of the Civil Code of the Russian Federation the owner had the right to demand from the violator of payment of compensation for each case of unauthorized use of result of intellectual activity or the allowed offense in general. The practice of application of the specified norm was rather inconsistent. So, many courts recognized that at violation of an exclusive right to some works or objects of allied rights the claimant can demand payment of compensation of 10 thousand rubles for each case of violation (Note 3). Compensation calculated in this way often was very high. As a rule, such situation was characteristic of instances of illegal copies distribution of musical and audiovisual works (Zimin, 2011, page 31).

Rather interestingly, there was a jurisprudence on the considered problem in the sphere of violation of exclusive rights and to other objects of copyright. For example, the individual entrepreneur of $D$. sold in the outlet two magnets containing the image of characters of animated series "Smeshariki" for the sum of 65 rubles. The owner of the exclusive copyright of images of characters of series demanded compensation 50 thousand rubles. Arbitration court, having reduced the amount of compensation, defined it in the sum of 20 thousand rubles - just on 10 thousand rubles for each case of violation (the decision of Arbitration court of Krasnoyarsk Territory, October 13, 2012 in the matter of No. A 3313424/2012).

Research of similar affairs shows, which, in fact, the sums of money many times exceeding the size of losses of owners of exclusive rights were collected from violators. E.P. Gavrilov noted "the measure of responsibility applied in such cases is, of course, disproportionate to consequences of violation of the right" (Gavrilov, 2012).

Thus, change of the situation fixed in paragraph 3 of item 3 of article 1252 of the Civil Code of the Russian Federation is based on that circumstance that collecting compensation for each case of violation of an exclusive right has the retaliatory character peculiar to measures of public responsibility.

Some new designs in the sphere of protection of the intellectual rights are debatable. So, in the legislation there is no direct answer to a question: whether the provisions fixed in item 4 of article 1250 of the Civil Code of the Russian Federation are, an obstacle to satisfaction of the regressing requirement to other violators of the person which paid the sum of losses in case of joint infliction of harm if thus this person acted is guilty (Note 4) In this regard the Presiding judge by the intellectual rights of L.A. Novoselova considers that in a situation of joint infliction of harm the reference to item 4 of article 1250 of the Civil Code of the Russian Federation is superficial as the regress ban in this case leads to an unfair situation, where one of abettor assumes all completeness of responsibility (Novoselova, 2015, page 244). It is possible to agree with the specified author that the above provisions are subject to application in other situation - when responsibility was conferred as like as two peas for the violations allowed by it in the absence of his fault, but this violation became possible because of another person (Novoselova, 2015, pages 244-245). 


\section{Conclusion}

Summarizing stated, it is possible to draw a conclusion that the intellectual rights owing to their specifics demand special system of ways of protection on which effectiveness these rights depends on existence. Legislative innovations in the sphere of intellectual rights protection in Russia have to promote efficiency of realization of ways of protection of the specified rights and strengthening of guarding function of civil law in the sphere of intellectual property.

\section{References}

Battakhov, P.P. (2013) Ways of protection of the rights for objects of industrial property//Modern right. No. 9. pp. 52-56.

Gavrilov, E. (2012) Jurisprudence according to copyright//Economy and the right. No. 4. pp. 55.

Civil law. In 4 volumes. V.1: General part: textbook / Edition of E.A. Sukhanova. M.: Wolters Kluver, 2010. pp. 613. (the author of chapter - E.A. Sukhanova).

Eremenko, V.I. (2007) The civil legislation codification completion of the Russian Federation//State and right. No. 10. pp. 43.

Zimin, V. (2011). About collecting compensation for each case of unauthorized use of works//IS. Copyright and allied rights. No. 11. pp. 31.

Krasavchikov, O.A. (1973). Responsibility, measures of protection and sanctions in the Soviet civil law//Problems civil - legal responsibility and protection of the civil rights. Sverdlovsk. pp. 9-12.

Novoselova, L.A. (2015) About some questions of responsibility for violation of exclusive rights//Legal protection of intellectual property: problems of the theory and practice. Collection of materials III of the International IP forum. M.: RG-Press. pp. 244-245.

Shevchenko, A.S. \& Shevchenko G.N. (2013) Delictual obligations in the Russian civil law: Manual. M.: Statute. pp. 60-61.

Note 1. (2007) Russian President's Council approved the civil legislation concept development of the Russian Federation for Codification and Enhancement of Civil Legislation on October 7, 2009.

Note 2. (2014) Article 1301, 1302 of Chapter 70 of the Civil Code of the Russian Federation; Article 1311 of Chapter 71 of the Civil Code of the Russian Federation; article 1406, 1406.1 of Chapter 72 of the Civil Code of the Russian Federation; item 4 of Article 1474 of paragraph 1 of Chapter 76 of the Civil Code of the Russian Federation; Article 1537 of paragraph 3 of Chapter 76 of the Civil Code of the Russian Federation in edition of the Federal Law of 12.03.2014 No. 35-Federal Law.

Note 3. (2011) The position of the Supreme Arbitration Court of the Russian Federation is on this matter noted in the Resolution of Presidium of the Supreme Arbitration Court of the Russian Federation of November 30, 2010 No. $10521 / 10$ (The Bulletin of the Supreme Arbitration Court of the Russian Federation. 2011. No. 2).

Note 4. In case of joint violation of an exclusive right, there is a common Liability of abettor (item 6.1 of article 1252 of the Civil Code of the Russian Federation). Thus, the debtor who fulfilled a solidary duty has the right of the regressing requirement to other debtors in equal shares minus the share falling on him (item 2 of article 325 of the Civil Code of the Russian Federation). 